\title{
Studies on antitumor activity spectrum of doxycycline
}

\author{
Bo Chen ${ }^{1,3}$, Hong-gang Zhou ${ }^{2,3}$, Wei Wang ${ }^{2,3}$, Wen-guang Gu², , Dong Zhao ${ }^{2,3}$, Peng Wang*3 \\ ${ }^{1}$ College of Biotechnology, Tianjin University of Science and Technology, Tianjin, China \\ ${ }^{2}$ State Key Laboratory of Medicinal Chemical Biology and College of Pharmacy, Nankai University, Tianjin, China \\ ${ }^{3}$ Tianjin Key Laboratory of Molecular Drug Research, Tianjin International Joint Academy of Biomedicine, Tianjin, China
}

Received: January 28, 2016

DOI: $10.5430 /$ jst.v6n1p103
Accepted: February 25, $2016 \quad$ Online Published: March 16, 2016

URL: http://dx.doi.org/10.5430/jst.v6n1p103

\begin{abstract}
In this study, in vitro (21 kinds of cell lines) and in vivo (four kinds of tumor-bearing mouse models) experiments were performed to determine the anticancer effect of doxycycline. This drug may elicit a strong inhibitory effect on cancer cells and improve the survival condition of mice. This study also preliminarily investigated the inhibitory effect of doxycycline on different kinds of tumor cells.
\end{abstract}

Key Words: Doxycycline, Cancer cell, Antitumor, Cell proliferation

\section{INTRODUCTION}

Novel efficacy of "old" drugs have been extensively investigated for use as new treatments. For instance, antibiotics can be used as anticancer drugs. ${ }^{[1-4]}$ Four to five classes of drugs, such as tetracyclines, can also be used to eradicate 12 cancer cell lines. ${ }^{[5]}$ Tetracyclines are cytotoxic to tumor cells. ${ }^{[6]}$ As a semi-synthetic tetracycline, doxycycline inhibits matrix metalloproteinase (MMP) activation, prevents cell proliferation, and downregulates DNA-dependent protein kinase. ${ }^{[7,8]}$

\section{MATERials AND MethodS}

\subsection{Materials}

Doxycycline was purchased from Sangon Biotech (Shanghai, China). Cyclophosphamide was procured from Alfa-Aesa (Ward Hill, USA). All of the cell lines were supplied by Kaiji Biotech (Nanjing, China). Cell culture media were obtained from Hyclone (Waltham, USA). Mice were purchased from the Academy of Military Medical Sciences of the Chinese PLA (Beijing, China).

\subsection{Methods}

All of the cell lines were cultured in a medium supplemented with $10 \%$ (v/v) heat-inactivated $\left(56^{\circ} \mathrm{C}, 30 \mathrm{~min}\right)$ fetal calf serum (Hyclone, USA) and maintained at $37^{\circ} \mathrm{C}$ in humidified air containing $5 \% \mathrm{CO}_{2}$. PC-3 cells were cultured in F12K medium. NCI-H446, A549, PLC/PRF/5, SMMC-7721, MuM2B, MuM2C, MCF-7, SGC-7901, SH-SY5Y, K562, and HL60 cells were cultured in RPMI1640 medium. HepG2, MHCC97H, MHCC97L, LOVO, A875, A375, MDA-MB231, PANC-1, ASPC-1, and HeLa cells were cultured in DMEM (high glucose) medium.

Cell viability was determined via an MTT assay. The cells (5 $\times 10^{3}$ cells/well) were seeded in 96-well culture plates. The cells were incubated overnight. Afterward, they were treated with various doxycycline concentrations $(0.00,0.39,0.78$, $1.56,3.12,6.25,12.5,25.00,50.00$, and $100.00 \mu \mathrm{M})$. After $48 \mathrm{~h}$ of incubation, $20 \mu \mathrm{l}$ of MTT was added at $37^{\circ} \mathrm{C}$ for $4 \mathrm{~h}$, and cell viability was determined. Then, $150 \mu \mathrm{l}$ of dimethyl sulfoxide was added to dissolve the formazan crystals. Opti-

\footnotetext{
* Correspondence: Peng Wang; Email: wangpeng5126@126.com; Address: Tianjin Key Laboratory of Molecular Drug Research, Tianjin International Joint Academy of Biomedicine, Tianjin, China.
} 
cal density was determined at $570 \mathrm{~nm}$ by using a microplate reader (Multiskan ${ }^{\mathrm{TM}}$ FC, Thermo Scientific, Waltham, MA, USA).

Five- to six-week-old male C57BL/6 and BAlB/c nu/nu mice were prepared for mouse and human tumorigeneses, respectively. They were maintained in a specific pathogen-free animal care facility in accordance with institutional guidelines. Tumor xenografts were established by subcutaneously injecting $1 \times 10^{7}$ cells suspended in phosphate buffered saline into the flank. The mice were randomly divided into five groups ( $n=10$ /group) 1 day after the tumor cells were inoculated. After the tumors reached an approximate volume of $100 \mathrm{~mm}^{3}$ (approximately 6 weeks after injection), the mice were treated with 60,30 , or $15 \mathrm{mg} / \mathrm{kg}$ doxycycline, $20 \mathrm{mg} / \mathrm{kg}$ cyclophosphamide, and saline via oral gavage once a day. Their body weights were measured at different time points after the tumor cells were inoculated. Tumor diameters were also measured every day. Tumor volumes were calculated according to the following equation: $\mathrm{V}=\mathrm{ab}^{2} / 2$, where $\mathrm{a}$ is the tumor length and $b$ is the tumor width. Seven weeks after the treatment was administered, all of the mice were euthanized, and xenografts were resected and measured. The inhibitory rates were calculated as $(\%)=\left(1-T_{i} / C_{i}\right) \times 100 \%$, where $\mathrm{T}_{i}$ is the tumor volume of the treated group and $\mathrm{C}_{i}$ is the tumor volume of the control group. Changes in weight were determined as $(\%)=\left(T_{w} / C_{w}-1\right) \times 100 \%$, where $\mathrm{T}_{w}$ is the body weight of the treated group and $\mathrm{C}_{w}$ is the body weight of the control group.

Data were expressed as means \pm standard deviation. Comparisons between the groups were performed through one-way ANOVA, followed by Bonferroni post hoc test (SPSS version 17.0, SPSS Inc., Chicago, IL, USA). The significance level was set at $P<.05$.

\section{Results}

Performing the MTT assay, we determined the effect of the $48 \mathrm{~h}$ doxycycline treatment on the cell viability of various cancer cell lines. We measured $\mathrm{IC}_{50}$ of the different cell lines to doxycycline. Doxycycline significantly inhibited the proliferation of these cells in a dose-dependent manner (see Table 1). $\mathrm{IC}_{50}$ of most cells was less than $5 \mu \mathrm{M}$, which was quite low. This result demonstrated that many cancer cell lines were very sensitive to doxycycline.

Tumor formation ability is an important indicator of cancer cell malignancy. Therefore, we investigated the inhibitory effect of doxycycline on tumor growth in vivo by using four tumor-bearing mouse xenograft models.
Table 1. $\mathrm{IC}_{50}$ dose of doxycycline for different cancer cell lines

\begin{tabular}{|c|c|c|}
\hline Cells & & $\mathrm{IC}_{50}(\mu \mathrm{M})$ \\
\hline \multirow{4}{*}{ Melanoma cells } & A875 & $3.10 \pm 0.33$ \\
\hline & A375 & $2.42 \pm 0.14$ \\
\hline & Mum2B & $2.75 \pm 0.55$ \\
\hline & Mum2C & $1.40 \pm 0.11$ \\
\hline \multirow{2}{*}{ Lung cancer cells } & NCI-H446 & $1.70 \pm 0.12$ \\
\hline & A549 & $1.06 \pm 0.13$ \\
\hline \multirow{2}{*}{ Hepatoma carcinoma cell } & PLC & $2.23 \pm 0.15$ \\
\hline & МНСС97H & $10.05 \pm 3.94$ \\
\hline \multirow{2}{*}{ Breast cancer cells } & MCF-7 & $2.09 \pm 0.03$ \\
\hline & MDA-MB-231 & $3.61 \pm 0.37$ \\
\hline \multirow{2}{*}{ Leukemia cells } & K562 & $1.45 \pm 0.10$ \\
\hline & HL60 & $1.48 \pm 0.22$ \\
\hline \multirow{2}{*}{ Pancreatic cancer } & PCNA-1 & $34.54 \pm 6.79$ \\
\hline & AsPC-1 & $29.34 \pm 6.17$ \\
\hline \multirow{2}{*}{$\begin{array}{l}\text { Human embryonic kidney } \\
\text { cells }\end{array}$} & HEK 293 & $11.85 \pm 1.07$ \\
\hline & HEK 293T & $2.47 \pm 0.39$ \\
\hline Gastric cancer cells & SGC-7901 & $2.45 \pm 0.26$ \\
\hline Cervical cancer cells & Hela & $4.08 \pm 0.19$ \\
\hline Neurobiastoma & SH-SY5Y & $3.70 \pm 0.14$ \\
\hline Colon cancer & LOVO & $0.91 \pm 0.15$ \\
\hline Prostate cancer cells & PC-3 & $2.35 \pm 0.13$ \\
\hline
\end{tabular}

Note. Each experiment was performed in triplicate. Results show the means of the three experiments, and the error bars represent standard deviation.

We analyzed the changes in the tumor volume and body weights of the mice treated with doxycycline and then compared them with those observed in the control group. The inhibition effect of doxycycline on the tumor cells was very evident compared with that of the positive drug control group (see Table 2). Doxycycline could significantly inhibit the proliferation of B16 melanoma cells, Lewis lung cancer cells, MCF-7 breast cancer cells, and NCI-H446 human small cell lung cancer cells.

The body weight of the doxycycline-treated mice was significantly higher than that of the control group. The body weights of the mice in the low-, middle-, and high-dose groups respectively treated with 15,30 , and $60 \mathrm{mg} / \mathrm{kg}$ doxycycline were also significantly higher than those of the mice 
in the cyclophosphamide-treated group.

Doxycycline increased the body weight of the mice and improved their survival conditions. This finding indicated that doxycycline exhibited a very good antitumor activity and caused few side effects. Doxycycline also elicited remarkable anti-tumor effects. Therefore, this drug can be applied to treat and prevent cancer.

Table 2. The changes of tumor volume and body weight compared with control group

\begin{tabular}{|c|c|c|c|c|c|c|c|c|c|}
\hline \multirow{3}{*}{\multicolumn{2}{|c|}{ Target drug }} & \multicolumn{8}{|c|}{ Observation } \\
\hline & & \multicolumn{4}{|c|}{ Inhibiting rates $(\%)$} & \multicolumn{4}{|c|}{ Weight change (\%) } \\
\hline & & B16 & Lewis & NCI-H446 & MCF-7 & B16 & Lewis & NCI-H446 & MCF-7 \\
\hline \multicolumn{2}{|c|}{$\begin{array}{l}\text { Cyclophosphamide } \\
(20 \mathrm{mg} / \mathrm{kg})\end{array}$} & 60.7 & 47.3 & 87.5 & 63.4 & -14.3 & -7.1 & -14.0 & -21.9 \\
\hline \multirow{3}{*}{ Doxycycline } & $15 \mathrm{mg} / \mathrm{kg}$ & 45.2 & 64.9 & 33.1 & 27.5 & +8.2 & +4.1 & -2.4 & -2.3 \\
\hline & $30 \mathrm{mg} / \mathrm{kg}$ & 56.3 & 74.2 & 57.1 & 41.2 & +13.3 & +7.4 & -2.7 & +2.3 \\
\hline & $60 \mathrm{mg} / \mathrm{kg}$ & 80.4 & 81.2 & 67.9 & 96.0 & +17.7 & +9.6 & -7.8 & +6.8 \\
\hline
\end{tabular}

\section{Discussion}

Doxycycline influences cell adhesion processes and the activity of focal adhesion kinase; for instance, this drug prevents cell adhesion during migration. ${ }^{[9]}$ Doxycycline induces the membrane expression of VE-cadherin on endothelial cells and prevents vascular hyperpermeability. ${ }^{[10]}$ Besides, doxycycline also inhibits metabolism and metastasis by interfering with MMPs and E-cadherin levels. ${ }^{[1]}$ Previous study had proved decreasing MMP activity could inhibit cancer cell invasion and metastasis, decreasing of E-cadherin expression is sufficient to confer metastatic ability to breast cancer. ${ }^{[12]}$ Doxycycline increases E-cadherin levels, decreases vimentin protein expression, which are two markers of invasiveness and metastasis, and inhibits EMT-related transcription fac- tor activities. ${ }^{[13,14]}$ Therefore, this drug elicits an antitumor effect through the combined action of various targets.

Our study revealed that doxycycline elicits a remarkable inhibitory effect on cancer cells. In our animal experiments, the inhibitory rates of doxycycline were higher than those of cyclophosphamide. Doxycycline could also improve the survival condition of mice. Therefore, doxycycline is a promising anticancer agent because it inhibits cancer cell proliferation, induces less toxic effects and causes fewer side effects than other drugs do.

\section{Conflicts of InTEREST Disclosure}

The author declares that there is no conflict of interest statement.

\section{REFERENCES}

[1] Ribeiro JA, Silva F, Pereira CM. Electrochemical study of the anticancer drug daunorubicin at a water/oil interface: Drug lipophilicity and quantification. Analytical chemistry. 2013; 85(3): 1582-90. PMid:23301839. http://dx.doi .org/10.1021/ac3028245

[2] Wang L, Meng Q, Wang C, et al. Dioscin restores the activity of the anticancer agent adriamycin in multidrug-resistant human leukemia K562/adriamycin cells by down-regulating MDR1 via a mechanism involving NF- $\kappa \mathrm{B}$ signaling inhibition. Journal of natural products. 2013; 76(5): 909-14. PMid:23621869. http://dx.doi.org/10. 1021/np400071c

[3] Chaoul N, Fayolle C, Desrues B, et al. Rapamycin impairs antitumor CD8+ T-cell responses and vaccine-induced tumor eradication. Cancer Research. 2013; 75(16): 3279-91. PMid:26122844. http://dx.doi.org/10.1158/0008-5472.CAN-15-0454

[4] Wu W, Dong Y, Gao J, et al. Aspartate-modified doxorubicin on its N-terminal increases drug accumulation in LAT1-overexpressing tumors. Cancer scienc. 2015; 106: 747-56. PMid:25867020. http: //dx.doi.org/10.1111/cas.12672

[5] Lamb R, Ozsvari B, Lisanti CL, et al. Antibiotics that target mitochondria effectively eradicate cancer stem cells, across multiple tumor types: Treating cancer like an infectious disease. Oncotarget. 2015; 6(7): 4569-84. PMid:25625193. http://dx.doi.org/10. 18632/oncotarget. 3174

[6] Richards C, Pantanowitz L, Dezube BJ. Antimicrobial and nonantimicrobial tetracyclines in human cancer trials. Pharmacological Research. 2011; 63(2): 151-6. PMid:20951804. http://dx.doi.o $\mathrm{rg} / 10.1016 / \mathrm{j} \cdot \mathrm{phrs} .2010 .10 .008$

[7] Lokeshwar BL. Chemically modified non-antimicrobial tetracyclines are multifunctional drugs against advanced cancers. Pharmacological Research. 2011; 63(2): 146-150. PMid:21093590. http://dx.doi.org/10.1016/j.phrs.2010.11.003

[8] Lamb R, Fiorillo M, Chadwick A, et al. Doxycycline down-regulates DNA-PK and radiosensitizes tumor initiating cells: Implications for more effective radiation therapy. Oncotarget. 2015; 6(16): 14005 25. PMid:26087309. http://dx.doi.org/10.18632/oncotarg et. 4159

[9] Sun T, Zhao N, Ni C, et al. Doxycycline inhibits the adhesion and migration of melanoma cells by inhibiting the expression and phosphorylation of focal adhesion kinase (FAK). Cancer letters. 2009; 285(2): 141-50. PMid:19482420. http://dx.doi.org/10.1016 /j.canlet.2009.05.004

Published by Sciedu Press 
[10] Fainaru O, Adini I, Benny O, et al. Doxycycline induces membrane expression of VE-cadherin on endothelial cells and prevents vascular hyperpermeability. The FASEB Journal. 2008; 22(10): 3728-35. PMid:18606869. http://dx.doi.org/10.1096/fj.08-110494

[11] Chen Z, Wang Y, Liu W, et al. Doxycycline inducible Kruppellike factor 4 lentiviral vector mediates mesenchymal to epithelial transition in ovarian cancer cells. Plos one. 2014; 9(8): e105331. PMid:25137052. http://dx.doi.org/10.1371/journal.pon e. 0105331

[12] Baranwal S, Alahari SK. Molecular mechanisms controlling Ecadherin expression in breast cancer. Biochemical and biophysi- cal research communications. 2009; 384(1): 6-11. PMid:19379710. http://dx.doi.org/10.1016/j.bbrc.2009.04.051

[13] Zhao Y, Yan Q, Long X, et al. Vimentin affects the mobility and invasiveness of prostate cancer cells. Cell biochemistry and function. 2008; 26(5): 571-7. PMid:18464297. http://dx.doi.org/10.10 $02 / \mathrm{cbf} .1478$

[14] Qin Y, Zhang Q, Lee S, et al. Doxycycline reverses epithelial-tomesenchymal transition and suppresses the proliferation and metastasis of lung cancer cells. Oncotarget. 2015; 6(38): 40667-79. PMid:26512779. 